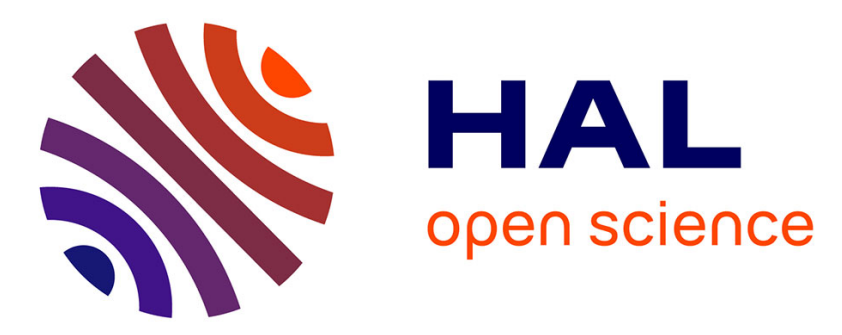

\title{
Comparative studies of three tropical wood species under compressive cyclic loading and various moisture content levels
}

Clauvy'S Arnaud Engonga Edzang, Claude Feldman Pambou Nziengui, Samuel Ikogou, Rostand Moutou Pitti

\section{To cite this version:}

Clauvy'S Arnaud Engonga Edzang, Claude Feldman Pambou Nziengui, Samuel Ikogou, Rostand Moutou Pitti. Comparative studies of three tropical wood species under compressive cyclic loading and various moisture content levels. SEMC 2019: The Seventh International Conference on Structural, Sep 2019, CapTown, South Africa. hal-02116767

\section{HAL Id: hal-02116767 \\ https://hal.science/hal-02116767}

Submitted on 1 May 2019

HAL is a multi-disciplinary open access archive for the deposit and dissemination of scientific research documents, whether they are published or not. The documents may come from teaching and research institutions in France or abroad, or from public or private research centers.
L'archive ouverte pluridisciplinaire HAL, est destinée au dépôt et à la diffusion de documents scientifiques de niveau recherche, publiés ou non, émanant des établissements d'enseignement et de recherche français ou étrangers, des laboratoires publics ou privés. 


\title{
Comparative studies of three tropical wood species under compressive cyclic loading and various moisture content levels
}

\author{
A.C. Engonga Edzang \\ Ecole Nationale des Eaux et Forêts, LaReVa Bois, BP 3960 Libreville, Gabon
}

C.F. Pambou Nziengui

Ecole Nationale des Eaux et Forêts, LaReVa Bois, BP 3960 Libreville, Gabon

Université Clermont Auvergne, CNRS, SIGMA Clermont, Institut Pascal, BP 10448, 63000 Clermont-

Ferrand, France

S. Ikogou

USTM, Ecole Polytechnique de Masuku, BP 901 Franceville, Gabon

\section{R. Moutou Pitti}

Université Clermont Auvergne, CNRS, SIGMA Clermont, Institut Pascal, BP 10448, 63000 ClermontFerrand, France

CENAREST, IRT, BP 14070, Libreville, Gabon.

\begin{abstract}
The forest represents more than $80 \%$ of the national territory, in Gabon, which makes more than 22 million hectares of potential forest and a significant added value for the field of wood construction. Also, with more than $1900 \mathrm{~mm}$ of annual precipitation, a relative humidity rate of $85 \%$ and an average temperature of $27^{\circ} \mathrm{C}$, the environmental conditions in Gabon seem harsh for wooden structures. Indeed, the literature shows that variations in climatic conditions $(\mathrm{RH}, \mathrm{T})$ but especially in the moisture content (MC) of wood, coupled with loadings, limit the life of wood in structures. This work deals with the study of the coupled impact of variations in the internal moisture content of wood and cyclic compression loading on the mechanical behavior of three tropical species (Iroko, Okume and Padouk). The results show that the module of elasticity and the maximal stress at the break of the species studied in this work is a function of the density of the species.
\end{abstract}

\section{Keywords: Tropical species; internal humidity impact; cyclic compressive loading}

\section{INTRODUCTION}

It is well known that the stresses suffered timber structures are mainly mechanical and environmental types. In addition, variations in climatic conditions (Relative Humidity RH, Temperature T) but especially in the Moisture Content (MC) of wood, coupled with mechanical loadings limit the life of wood in structures (Pambou Nziengui et al. 2017). Thus, with more than $1900 \mathrm{~mm}$ of annual precipitation, a relative humidity rate of $85 \%$ and an average temperature of $27^{\circ} \mathrm{C}$, the environmental conditions in Gabon seems harsh for wood in structures. This work therefore deals with the study of the coupled impact of the variations of MC of wood and the cyclic compressive loading on the mechanical behavior of three tropical species (Iroko, Okume and Padouk). The main objective of this work is to better understand the mechanical behavior of these three tropical species subjected to cyclic compressive loading.

\section{MATERIALS AND METHOD}

The experimental device is compound of: the specimens of Iroko (I), Okume (O) and Padouk (P), which have the dimensions of $20 \times 20 \times 60 \mathrm{~mm}^{3}$, size according to the standard requirement NF EN 408 (Fig. 1); a testing machine (united testing systems machine) equipped with a system for the acquisition of data during the period of the test (Figs 2b, $c, d)$. Figure 2a shows the protocol used for the following of the MC on the specimens tested. Each specimen studied in this work, were subjected to 5 cycles of compressive loading (loading-unloadingreloading), where the maximum load applied (1640 $\mathrm{N}$ ) has been taken at $10 \%$ of the maximum breaking loading of the species $\mathrm{O}$.

For the determination of $\mathrm{MC}$, each specimen has been put on filled drums until their saturation and the empirical equation (1) were used to determine the specifical MC arrested:

$\operatorname{MC}(\%)=\left[\left(M_{H}-M_{0}\right) / M_{0}\right] \times 100$ 


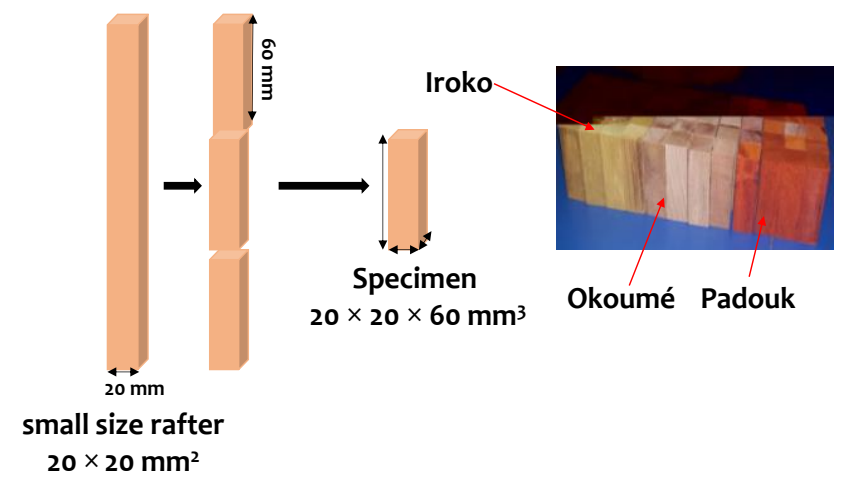

Figure 1. General geometric configuration of test specimens

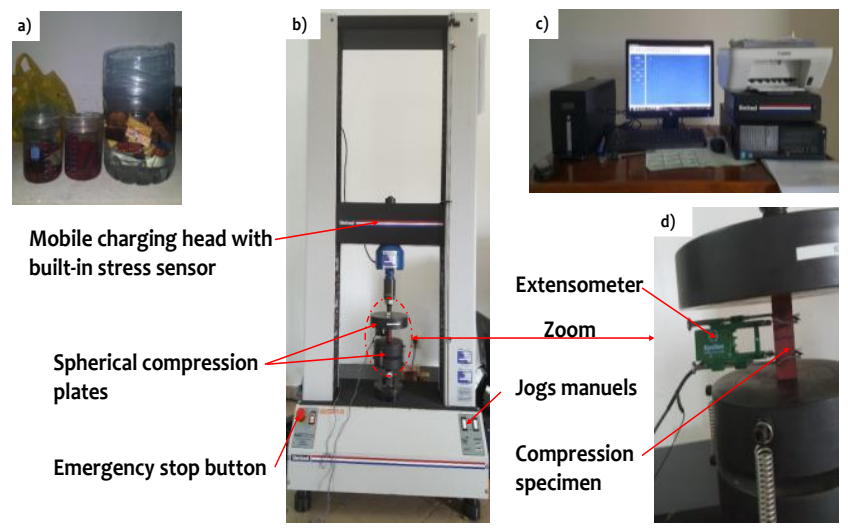

Figure 2. Experimental setup of a compression test: (a) Humidification of specimens; (b) test bench; (c) data acquisition system; (d) Test specimen in compression test

\section{RESULTS AND DISCUSSIONS}

In first, the static tests of compression were performed, for their characterization on each specimen studied. After, the maximum breaking loading and module of elasticity (MOE) of each species have been determined. The table 1 below shows the average values of these parameters.

Table 1. Average of the mechanical characteristics obtained for each species in static compression of Iroko, Okume and Padouk

\begin{tabular}{lcc}
\hline Parameter & $\mathrm{E}_{\mathrm{L}}^{\mathrm{c}}(\mathrm{MPa})$ & $\sigma_{\max }^{\mathrm{c}}(\mathrm{MPa})$ \\
\hline Okoume & $12633 \pm 2422.87$ & $43.97 \pm 11.65$ \\
Iroko & $13093 \pm 1573.30$ & $47.65 \pm 20.62$ \\
Padouk & $17093 \pm 2261.57$ & $55.81 \pm 8.47$ \\
\hline
\end{tabular}

As expected, we note in Table 1 that $\mathrm{P}$ is the specie that has the highest maximum stress at break in static compression, followed respectively by I and $\mathrm{O}$. Their respective densities could easily explain this result. Indeed, $\mathrm{P}$ is the most dense species (with
$0.728 \pm 0.023$ of density), its maximum stress at break is therefore the highest, followed respectively by $\mathrm{I}$ and $\mathrm{O}$ (with respective densities of $0.474 \pm$ 0.021 and $0.469 \pm 0.007)$. This observation is also valid for the MOE, $\mathrm{P}$ always having the value of the highest MOE, followed by I and O.

The values of the MOE obtained experimentally differ from those obtained by the (Gérard et al, 2004 ; Martin et al, 2016) of 23\%, 2\% and 7\%, respectively among $\mathrm{O}$, I and $\mathrm{P}$. Likewise, the maximum stresses differ by $18 \%, 12 \%$ and $14 \%$ respectively among $\mathrm{O}$, I and P. These differences between the experimental values obtained and the theoretical values can partly be explained by the origin of the species from which the specimens were taken. Indeed, several studies have shown that by its biological origin, the characteristics of wood material can vary between species, within the same species and within the same tree (Almeida et al., 2006).

\section{REFERENCES}

Almeida, G., 2006. Influence de la structure du bois sur ses propriétés physicomécaniques à des teneurs en humidité élevées. Université de Laval : Thèse

Gérard J., Beauchêne J., Fouquet D., Guibal D., Langbour P., Thévenon M-F., Thibaut A., Vernay M. (2004) Caractéristiques technologiques de 215 essences tropicales. Montpellier: CIRAD-Forêt, 1 Cd-Rom

Martin, P. et Vernay, M., 2016. Guide d'utilisation des bois africains éco-certifiés en Europe. Paris: ATIBT

Pambou Nziengui C.F., Ikogou S., Moutou Pitti R. (2017) Impact of cyclic compressive loading and moisture content on the mechanical behavior of Aucoumea Klaineana Pierre. Wood Material Science and Engineering, 13, 190196

\section{ACKNOWLEDGEMENTS}

The authors thank the Network of Forestry and Environmental Training Institutions of Central Africa (RIFFEAC) for the implementation of the Wood Science Master of the Ecole Nationale des Eaux et Forêts (ENEF - GABON) as well as the PEPS project CNRS "RUMO" and the Auvergne Rhône-Alpes Region (AURA) for financial support thanks to the SCUSI project. 